\title{
EFFECTS OF TANK BACKGROUND COLOUR ON GROWTH PERFORMANCE AND FEED UTILIZATION OF AFRICAN CATFISH Clarias gariepinus (Burchell, 1822) FINGERLINGS
}

\author{
Victor Tosin Okomoda ${ }^{*}$, Lateef Oloyede Tiamiyu², Gabriel Wase ${ }^{1}$ \\ ${ }^{1}$ Department of Fisheries and Aquaculture, University of Agriculture Makurdi, Nigeria \\ ${ }^{2}$ Department of Aquaculture and fisheries, University of Ilorin, Nigeria \\ *Corresponding Author, Email: okomodavictor@yahoo.com
}

\section{ARTICLE INFO}

Received: 17 February 2016

Received in revised form: 15 November 2016

Accepted: 6 December 2016

Available online: 20 January 2017

\begin{abstract}
The performance of Clarias gariepinus (Burchell, 1822) fingerlings reared in white, green, blue, black and red coloured tanks was investigated. Each colour was tested in triplicate $1 \mathrm{~m}^{3}$ tanks with an initial stocking density of 100 fingerlings per tank (1.07 g). Fish were fed a commercial diet at $5 \%$ body weight per day for eight weeks. Fish weights were sampled every 2 weeks to adjust feeding rates. Tank colour had a significant effect $(\mathrm{P}<0.05)$ on the overall performance of the fingerlings. Rearing in black tanks resulted in a higher daily feed intake $(0.44 \mathrm{~g})$ and better growth performance when compared to other tank colours, while the poorest performance was observed in blue and green tanks. Carcass protein and fat content at 8 weeks revealed a trend similar to that observed for growth. Also, serum glucose tests showed higher levels in light background tanks and were thought to be an indication of stress. Survival was not affected by tank colour. It was concluded that dark-coloured tanks such as black or red were better in comparison to light-coloured tanks for the rearing of African catfish fingerlings.
\end{abstract}

\section{Keywords: \\ Blood glucose \\ Body colour \\ Feed intake \\ Fish welfare \\ Stress \\ Muscle}

Okomoda, V. T., Tiamiyu, L. O., Wase, G. (2017): Effects of tank background colour on growth performance and feed utilization of African catfish Clarias gariepinus (Burchell, 1822) fingerlings. Croatian Journal of Fisheries, 75, 5-11. DOI: $10.1515 / \mathrm{cjf}-2017-0002$.

\section{INTRODUCTION}

Aquaculture is an important provider of high-quality animal protein and other essential nutrients (Tacon and Forster, 2001). Aquaculture has been one of the fastest growing food production segments in the world with an overall annual growth rate of over $11 \%$ since 1984 (De Silva, 2001; Tacon and Forster, 2001; FAO, 2007). However, to maintain the current level of per capita fish consumption and prevent a reduction in global per capita fish supply, it is predicted that global aquaculture production should increase by two and half times by 2030 (FAO, 2014). Many environmental, nutritional and genetic parameters have been studied in an attempt to improve performance of fish and increase aquaculture production; notable among these are studies on welfare requirement within the culture systems (Appelbaum and McGeer, 1998; Almazán Rueda, 2004; Solomon and Okomoda, 2012a; Okomoda et al., 2016).

Tanks used for aquaculture activities are made of various materials including plastic, concrete, glass and fiberglass, and the choice of the background colour is often by 
chance (Opiyo, 2010). Research on several fish species has indicated that tank background colour is an important factor to consider in the culture of fish (Martin-Robichaud and Peterson, 1998; Papoutsoglou et al., 2000; Rotllant et al., 2003; Papoutsoglou et al., 2005; Martinez-Cardenas and Purser, 2007; Karakatsouli et al., 2007; Eslamloo et al., 2007, etc.). Background colours may induce a variety of responses in relation to food intake, stress, growth, survival and even social interaction of fish (Höglund et al., 2002; Merighe et al., 2004). Hence, to achieve better performance in fish production, optimization of the environmental conditions is necessary. The growing awareness in society about animal welfare also puts increasing demands on the culture conditions in fish farming facilities (Solomon and Okomoda, 2012a).

The results of various studies on the effect of background colour on fish performance are largely dependent on the species used, stage of development and colour selection for the investigation. While extensive literature abounds for temperate species on the subject matter (Stefansson and Hansen, 1989; Papoutsoglou et al., 2000, 2005; Rotllant et al., 2003), only a few studies are available for tropical fishes (especially African catfish). Bardócz et al. (1999) reported no significant differences in growth for larvae and fry of $C$. gariepinus reared with black and white background. Also, Ekokotu and Nwachi (2014) had similar observation with green, blue and white backgrounds. To our knowledge, performances of fingerlings reared in differently coloured tanks have not been reported. Accordingly, the present study was designed to better evaluate the effect of tank colouration on fingerlings of African catfish by studying side-by-side previously reported colours for larvae and fry trials, as well as using a red tank background which is now a prominent tank colour used among fish farmers in Nigeria (personal communications).

\section{MATERIALS AND METHODS}

The study was conducted at the Departmental of Fisheries and Aquaculture, University of Agriculture Makurdi, Benue State, Nigeria. 1600 fingerlings of African catfish Clarias gariepinus were obtained from the University fish farm (collected from earth ponds) and acclimatized in concrete tanks for two weeks before distribution into various coloured concrete tanks (measuring $1 \times 1 \times 1 \mathrm{~m}^{3}$ ) prepared for this study. The different background colours were achieved by using appropriate commercial oil paints for the inner portions of each tank. The tanks were then filled with water with the addition of chicken droppings. This was left for two weeks for pond curing to be completed.

A total of one hundred fingerlings $(1.07 \mathrm{~g})$ were randomly stocked in each triplicate concrete tank of white (HEX \#FFFFFF, RGB 255, 255, 255), green (HEX \#28B200, RGB
40, 178, 0), blue (HEX \#4074FF, RGB 64, 116, 255), black (HEX \#000000, RGB 0, 0, 0) and red (HEX \#D41303, RGB $212,19,3$ ) colouration (colour code according to http:// htmlcolorcodes.com/). All tanks were supplied with fresh de-chlorinated tap water in a flow-through system (flow rate 4 litres/minute) throughout the time of the experiment. Water levels in the tanks were kept constant at $75 \%$ of the tank height. The tops of the tanks were covered using mosquito nets of mesh size $0.2 \mathrm{~mm}$ to prevent entrance of predators and escape of stocked fish. Water quality was examined weekly throughout the period of the experiment and was maintained within recommended ranges for the rearing of tropical fishes $\left(\mathrm{DO}=5.25-5.16 \mathrm{mg}^{-1}\right.$, temperature $=25.80-25.40^{\circ} \mathrm{C}, \mathrm{pH}=7.41-7.36$ and electric conductivity = 377 - 360). Dissolved oxygen was measured using a 19142 HANNA portable meter (produced in Romania), while temperature, $\mathrm{pH}$ and electric conductivity were measured using HANNA H-198129 multi-parameter water checker (produced in Romania).

Fish were hand-fed twice a day (08:00 a.m. and 06:00 p.m.) $0.5 \mathrm{~mm}$ Coppens commercial diet (8.2\% moisture, $9.5 \%$ ash, $45 \%$ crude protein, $12 \%$ fat, $1.5 \%$ crude fiber and $23.8 \%$ carbohydrates) at a rate of $5 \%$ of their body weight per day. Fingerlings were reared under the prevailing natural photoperiod of 13-hour daylight and 11-hour darkness. Fingerlings from each tank were bulk-weighted every two weeks to determine their weight gained after which feeds were adjusted accordingly. After feeding the fish for eight weeks (56 days), growth performance and nutrient utilization were assessed in triplicates for each treatment on the $57^{\text {th }}$ day using the following formulae:

(a) Mean Weight Gain (MWG, g/individual) $=W t_{2}-W t_{1}$ (b) Specific Growth Rate (SGR, \%/day) $=\frac{\log _{\mathrm{e}}\left(w t_{2}\right)-\log _{\mathrm{e}}\left(w t_{1}\right)}{t_{2}-t_{1}}$ Where $\mathrm{Wt}_{1}=$ Initial weight $\mathrm{Wt}_{2}=$ Final weight $\mathrm{T}_{2}-\mathrm{T}_{1}=$ Duration in days between taking the initial and final weight.

(c) Daily feed intake $(\mathrm{DFI})=\frac{\text { Total feed intake }}{\text { Duration of the experiment }}$

(d) Feed conversion ratio $(F C R)=\frac{\text { Total feed intake }}{\text { Weight gain }}$

(e) $\%$ survival rate $=\frac{\text { Total number of fish- mortality }}{\text { Total number of fish }} \times 100$

Also, at the end of the eight-week feeding trial, body colouration was determined according to the method reported by Solomon and Okomoda (2012b) on all the surviving fish from each treatment. Three teams of four previously trained observers were used to describe body colouration based on the IT8 colour target chart developed by EGM laboratories (Rodriguez, 2013). Body colouration observed was described as "Light (16B-16E), Black (16F-16I which is assumed as the normal colouration observed in the fish before the start of the study) and Deep black (16J-16L)". 
Proximate compositions of the carcass (three fish per tank) of fish were also determined before and after the feeding trial using official methods as stated by AOAC (2000).

Blood samples from three sedated fish $\left(150 \mathrm{mg} \mathrm{L}^{-1}\right.$ solution of tricaine methane sulphonate MS222) from each treatment were collected from the caudal fin artery-vein complex and glucose determined by placing a drop of the blood sample on strips connected to an Accu-chek active kit (model $\mathrm{CEOOHH}$ ) in situ. Blood glucose determination was done on the $57^{\text {th }}$ day of the experiment (last sampling day) at about the usual time of feeding the fish in the mornings (8:00 a.m.). Summary statistics of the different variables measured across the treatments were obtained using Minitab 14 for Windows. Anderson-Darling test was used to test for normality of the data set. The data was then subjected to Analysis of variance and significant differences occurred; separation of means was evaluated using Fisher's least significant difference test. Effects of tank colour on blood glucose were tested using a nested ANOVA.

\section{RESULTS}

The growth performance and feed utilization of African catfish fingerlings fed in differently coloured tanks are presented in Table 1. The mean performance of African catish fingerlings was markedly affected by tank colouration (ANOVA, Table 1).

Table 1. Analysis of variance of the growth performance and feed utilization and nested analysis of variance of blood glucose of African catfish fingerlings raised in differently coloured tanks

\begin{tabular}{lccc}
\hline & DF & F & P-value \\
\hline MWG & 4,10 & 15.34 & 0.001 \\
SGR & 4,10 & 12.79 & 0.031 \\
DFI & 4,10 & 13.59 & 0.021 \\
FCR & 4,10 & 3.67 & 0.093 \\
Survival & 4,10 & 2.50 & 0.171 \\
Blood glucose & 10,30 & 8.99 & 0.031 \\
\hline \hline
\end{tabular}

Mean weight gain and specific growth rate were significantly higher in tanks with the black background ( $14.47 \mathrm{~g}$ and 4.79 g.day ${ }^{-1}$ respectively) compared to other tank colours (Table 2). Poorest performance values were recorded for green and blue coloured tanks. Daily feed intake in differently coloured tanks also followed the same pattern (Table 2), although there were no differences for feed conversion ratio between various tank colours (ANOVA, Table 1). Similarly, survival was not affected by tank colouration (ANOVA, Table 1). Serum glucose revealed higher values in green and blue background tanks ( 4.6 and $4.8 \mathrm{mmol} \cdot \mathrm{L}^{-1}$ respectively) while the lowest value was observed in black background tanks (3.0 $\mathrm{mmol}^{-1} \mathrm{~L}^{-1}$ ) (Table 2).
Table 2. Growth performance, feed utilization and blood glucose of African catish fingerlings raised in differently coloured tanks (mean initial weight of $1.07 \pm 0.20$ )

\begin{tabular}{lccccc}
\hline Parameters & \multicolumn{5}{c}{ Tank colour } \\
& White & Blue & Green & Red & Black \\
\hline MWG (g) & $13.92 \pm$ & $13.82 \pm$ & $13.81 \pm$ & $14.18 \pm$ & $14.47 \pm$ \\
& $0.05^{\mathrm{c}}$ & $0.15^{\mathrm{c}}$ & $0.11^{\mathrm{c}}$ & $0.07^{\mathrm{b}}$ & $0.05^{\mathrm{a}}$ \\
SGR (gday ${ }^{-1}$ ) & $4.72 \pm$ & $4.70 \pm$ & $4.68 \pm$ & $4.71 \pm$ & $4.79 \pm$ \\
& $0.03^{\mathrm{b}}$ & $0.05 \mathrm{~b}^{\mathrm{c}}$ & $0.09^{\mathrm{c}}$ & $0.10^{\mathrm{b}}$ & $0.06^{\mathrm{a}}$ \\
DFI (g) & $0.43 \pm$ & $0.42 \pm$ & $0.42 \pm$ & $0.44 \pm$ & $0.44 \pm$ \\
& $0.05^{\mathrm{c}}$ & $0.03^{\mathrm{d}}$ & $0.12^{\mathrm{d}}$ & $0.02^{\mathrm{b}}$ & $0.07^{\mathrm{a}}$ \\
FCR & $1.71 \pm$ & $1.71 \pm$ & $1.70 \pm$ & $1.72 \pm$ & $1.72 \pm$ \\
& 0.11 & 0.12 & 0.10 & 0.12 & 0.09 \\
Survival (\%) & $97.50 \pm$ & $90.00 \pm$ & $90.00 \pm$ & $92.50 \pm$ & $92.50 \pm$ \\
& 2.50 & 0.50 & 1.00 & 2.50 & 2.50 \\
Blood & $4.50 \pm$ & $4.80 \pm$ & $4.60 \pm$ & $3.30 \pm$ & $3.00 \pm$ \\
glucose $_{\text {(mmolL }}^{-1}$ ) & $0.95^{\mathrm{b}}$ & $0.07^{\mathrm{a}}$ & $0.05^{\mathrm{b}}$ & $0.34^{\mathrm{c}}$ & $0.03^{\mathrm{d}}$ \\
\hline \hline
\end{tabular}

Mean \pm SE in the same row with different superscripts differ significantly (Fisher's least significant difference test, $\mathrm{P}<0.05$ )

The effect of tank colour on carcass analysis is presented in Table 3. Higher crude protein and fat levels were recorded in fish reared in tanks with black background $(18.11 \%$ and $3.28 \%$, respectively) compared to other colours (Table 4). The lowest values were observed in blue tanks (17.99\% and $2.97 \%$, respectively). For all background colours tested values recorded for carcass protein were significantly higher than that measured initially $(7.21 \%)$, while those for fat decreased when compared against initial $(4.70 \%)$ values (Table 4). Fish also tended to deviate from starting coloration with the trend suggesting lighter colouration for fish reared in lighter coloured tanks (white, green and blue), while those raised in dark-coloured tanks (red and black) had darker colouration.

Table 3. Analysis of variance of proximate composition of African catfish fingerlings raised in differently coloured tanks

\begin{tabular}{lccc}
\hline \hline Parameters & DF & F & P-value \\
\hline Moisture & 4,10 & 11.46 & 0.001 \\
Ash & 4,10 & 11.84 & 0.001 \\
Fat & 4,10 & 15.07 & 0.001 \\
Fibre & 4,10 & 3.83 & 0.087 \\
Protein & 4,10 & 12.27 & 0.001 \\
Nitrogen Free Extract & 4,10 & 38.51 & 0.001 \\
\hline \hline
\end{tabular}


Table 4. Colouration and proximate composition of carcass of African catfish fingerlings reared in differently coloured tanks

\begin{tabular}{lcccccc}
\hline Parameters & & \multicolumn{5}{c}{ Tank colour } \\
& Initial & \multicolumn{5}{c}{} \\
& & White & Blue & Green & Red & Black \\
\hline Colouration & Black & Light & Light & Light & Black & Deep \\
of fish flesh & & & & & & Black \\
Moisture & 66.99 & $63.79 \pm$ & $63.66 \pm$ & $63.59 \pm$ & $64.54 \pm$ & $64.55 \pm$ \\
(\%) & $\pm 0.11^{\mathrm{a}}$ & $0.10^{\mathrm{d}}$ & $0.21^{\mathrm{e}}$ & $0.31^{\mathrm{f}}$ & $0.11^{\mathrm{c}}$ & $0.50^{\mathrm{b}}$ \\
Ash (\%) & $3.32 \pm$ & $2.12 \pm$ & $2.04 \pm$ & $1.98 \pm$ & $1.98 \pm$ & $2.01 \pm$ \\
& $0.33^{\mathrm{a}}$ & $0.51^{\mathrm{b}}$ & $0.14^{\mathrm{c}}$ & $0.14^{\mathrm{d}}$ & $0.15^{\mathrm{d}}$ & $0.31^{\mathrm{cd}}$ \\
Fat (\%) & $4.70 \pm$ & $3.05 \pm$ & $2.97 \pm$ & $2.82 \pm$ & $3.27 \pm$ & $3.28 \pm$ \\
& $0.13^{\mathrm{a}}$ & $0.20^{\mathrm{c}}$ & $0.03^{\mathrm{d}}$ & $0.30^{\mathrm{e}}$ & $0.51^{\mathrm{b}}$ & $0.21^{\mathrm{b}}$ \\
Fibre (\%) & $2.51 \pm$ & $1.28 \pm$ & $1.33 \pm$ & $1.24 \pm$ & $1.32 \pm$ & $1.30 \pm$ \\
& $0.11^{\mathrm{c}}$ & 0.25 & 0.22 & 0.14 & 0.21 & 0.45 \\
Protein (\%) & $7.21 \pm$ & $18.06 \pm$ & $17.99 \pm$ & $17.86 \pm$ & $18.04 \pm$ & $18.11 \pm$ \\
& $0.22^{\mathrm{c}}$ & $0.11^{\mathrm{c}}$ & $0.13^{\mathrm{d}}$ & $0.54^{\mathrm{e}}$ & $0.32^{\mathrm{b}}$ & $0.51^{\mathrm{a}}$ \\
Nitrogen & 15.18 & $11.73 \pm$ & $12.02 \pm$ & $12.52 \pm$ & $10.86 \pm$ & $10.76 \pm$ \\
Free & $\pm 0.19^{\mathrm{a}}$ & $0.03^{\mathrm{d}}$ & $0.21^{\mathrm{c}}$ & $0.13^{\mathrm{b}}$ & $0.41^{\mathrm{e}}$ & $0.33^{\mathrm{f}}$ \\
Extract (\%) & & & & & & \\
\hline
\end{tabular}

Mean \pm SE in the same row with different superscripts differ significantly $(\mathrm{P}<0.05)$

\section{DISCUSSION}

Hecht and Appelbaum (1987) had earlier postulated that growth performance of African catish cannot only be attributed to the quality of diet but also to the hatchery conditions under which they are reared. This hypothesis is justified by the results from the current study. The experiment described here recorded significant differences in performance of fish reared in differently coloured tanks, with black and red colours resulting in the best performance of African catfish fingerlings.

The growth of different fish species cultured with different background colours has received some attention and performance seems to be species-specific (McLean et al., 2008). While some fish species may perform best in dark tanks (Nile Tilapia Oreochromis niloticus (Linnaeus, 1758) Jegede, 2011), others favour lighter backgrounds (southern flounder Paralichthys lethostigma (Jordan and Gilbert, 1884) Henne and Watanabe, 2003) and others are reported not to be affected by differences in background colour (Atlantic salmon Salmo salar (Linnaeus, 1758) Steffansson and Hansen, 1989, cod Gadus morhua (Linnaeus, 1758) Papoutsoglou et al. 2000; Bransden et al., 2005 and potbellied seahorse Hippocampus abdominalis (Lesson, 1827) Martinez-Cardenas and Purser, 2007). The differences between species could simply reflect variations in the feeding biology of the fish under consideration.

For fish species or developmental stages dependent on vision for feeding, contrasting background and feed, and light intensity may be more important for facilitating prey capture than for tactile predators (Ostrowski, 1989; Cox and Pankhurst, 2000; Biswas et al. 2006; Strand et al. 2007), as if a food item does not visually stand out well against a background, it becomes difficult to capture and consume, resulting in poor growth rate and higher mortalities in fish larvae and post-larvae (Yasharian et al., 2005). Tank colour has previously been observed to be of relevance for some species of visual predators only in suboptimal light conditions (Strand et al., 2007), which may explain the lack of effect of tank colour on performance of African catish larvae reared in black and white tanks observed by Bardócz et al. (1999) and Ekokotu and Nwachi (2014) under optimal light conditions. The importance of optimal combinations of tank colour and light conditions on fish performance is further exemplified by Dolphin fish larvae (Coryphaena hippurus Linnaeus, 1758) which, when reared in white tanks, will exhibit shaking of the head from side to side, while larvae grown in black tanks do not display this characteristic. This behaviour in white tanks has been attributed to an attempt to focus on the food item available (Ostrowski, 1989). Optimization of rearing conditions and knowledge of fish feeding behaviour is thus of vital importance for successful fish culture.

Physiological studies of African catfish reveal a relatively small eye diameter to body size compared to other teleost fish, which may have strong consequences for the species mode of feeding (Solomon and Okomoda, 2012a) and subsequent performance in culture. The possession of some adaptive features such as barbels is thought to be one of the most important features used in searching and capture of food (Solomon and Okomoda, 2012a), and Billard and Lecointre (2001) suggested that the possession of highly specialized organs such as a rostrum, ampulla of Lorenzini and barbels may make these fishes light-independent during feeding. Although African catfish is both a nocturnal and a daylight feeder, vision is not considered to be the major factor in search and capture of food (Hecht and Appelbaum, 1987), making the species less vulnerable to suboptimal rearing conditions in regard to feeding conditions.

However, Britz and Pienaar (1992) reported that African catfish have a preference for darkness, and Almazán Rueda (2004) has observed avoidance of light and a preference for dark areas to be typical characteristics among African catfish juveniles. Hence, the lower growth performance and feed intake recorded in light-coloured tanks (such as white, green and blue backgrounds) in this study may be due to increased activity of searching for cover, as observed by Appelbaum and McGeer (1998) and Appelbaum and Kamler (2000). This suggestion would appear reasonable, given the high 
blood glucose level recorded in fish reared in light-coloured tanks when compared to the darker ones, which may be an indication of stress (Pottinger et al., 2002; Martínez-Porchas et al., 2009; Srivastava and Choudhary, 2010; Solomon and Okomoda, 2012b). However, the feed conversion ratio did not differ between fish in differently coloured tanks in this study. This indicates that the ingested energy was equally well utilized for growth in all colour treatments, thus the fish did not experience increased energy expenditures as related to stress reactions in light-coloured tanks, or that the resulting energy expenditures associated to stress responses were too low to be manifested in the FCR. Regardless, based on our results, we suggest that for this species, fish habitat preferences (dark versus light habitats) may be more important for optimizing fish performance in culture than feed contrast.

Tank background colour is also known to influence skin pigmentation (Eslamloo et al., 2007). In accordance with results obtained by Bardócz et al. (1999) for African catfish larvae, dark tank colours resulted in darker fish in this study. Solomon and Okomoda (2012b) have stated that coloration in African catfish is unstable and can change within a few hours of exposure to a different condition, which has been attributed to the use of colour change as a camouflage response. It can be hypothesised that the ability to adjust the body colour in accordance to the surroundings may act to reduce potential stress induced by suboptimal rearing conditions. However, in this study, despite adjusting to lighter colouration in light tanks, performance of the fish was still negatively affected by the tank colouration, indicating that the adjustment of body coloration did not outweigh the potential discomfort perceived by the fish in light tanks.

According to Fafioye et al. (2005), carcass protein addition and the corresponding increase in the structural tissues such as muscles is considered beneficial. The level of nutrient utilization and retention in carcass of fish is related to both the dietary protein levels and the availability of non-protein energy sources (Abbas, 2007; Manjappa et al., 2011). The significant changes recorded in the proximate composition of fish in this study may however be a function of increased or reduced activity in the culture tanks since the same feed was fed to all the groups. Although studies on proximate composition of fish reared in differently coloured tanks is scarce, increases in protein as well as fat could be linked to fish behaviour and preferences for dark tanks. Hence, less energy may be required for fish activity in dark tanks in comparison to light tanks, allowing for an increased protein and fat deposition in the fish reared in the black and red tanks compared to the white, green and blue tanks (Ozorio, 2008; Palstra and Planas, 2012). However, there may be species specific differences in energy allocation and biomass gain in relation to activity (Khan et al., 2014). Hence, the need for similar research for other species still exists.

\section{CONCLUSIONS}

In the present study on African catfish juveniles, tank colour had significant impacts on growth performance and feed intake. It is, therefore, important from a production perspective that conscious effort should be channelled into selection of appropriate background tank colours for rearing of fish. For African catfish juveniles, darker coloured tanks (black and red) enhance performance. Other colours may have beneficial effects which warrant attention. Future research should also further investigate the stress response which may influence overall animal health and well-being as well as play a part in cannibalism and other behavioural responses.

\section{ACKNOWLEDGEMENTS}

Authors are grateful to the management of the University of Agriculture Makurdi where this research was undertaken. Authors are also thankful for the phenomenal contributions of the two anonymous reviewers of this manuscript.

\section{Sažetak}

\section{UČINCI POZADINSKE BOJE BAZENA NA BRZINU RASTA I ISKORIŠTAVANJE HRANE MLAĐI AFRIČKOG SOMA, Clarius gariepinus (Burchell, 1822)}

U ovom radu istraživana je brzina rasta mlađi Clarius gariepinus (Burchell, 1822) uzgajanih u bijelim, zelenim, plavim, crnim i crvenim bazenima. Svaka boja testirana je na triplikatu $1 \mathrm{~m}^{3}$ bazenu s početnom gustoćom mlađi od 100 jedinki po bazenu ( $1,07 \mathrm{~g}$ ). Ribe su dnevno hranjene komercijalnom hranom na $5 \%$ tjelesne težine tijekom osam tjedana. Težina ribe je mjerena svaka 2 tjedna kako bi se prilagodila stopa ishrane. Boja bazena imala je značajan utjecaj $(P<0,05)$ na ukupne performanse mlađi. Uzgoj $u$ crnim bazenima rezultirao je većim dnevnim unosom hrane $(0,44 \mathrm{~g})$ i boljom performansom rasta u usporedbi s drugim bojama bazena, dok je najslabiji rast zabilježen u plavim i zelenim bazenima. Koncentracija proteina i masti tijekom osam tjedana imala je sličan trend kao i performansa rasta. Također, testovi glukoze u serumu za koju se smatra da je pokazatelj stresa pokazali su veću razinu u svijetloj pozadini bazena. Na postotak preživljavanja boja bazena nije utjecala. Zaključeno je da su za uzgoj mlađi afričkog soma bolji bazeni tamne boje, poput crne ili crvene, bolji u odnosu na svijetlo obojene bazene.

Ključne riječi: glukoza u krvi, boja tijela, unos hrane, stres, mišič 


\section{REFERENCES}

Abbas, E. F. (2007): Effect of dietary oil sources and levels on growth, feed utilization and whole-body chemical composition of common carp, Cyprinus carpio L. fingerlings. Journal of Fisheries \& Aquaculture Science, 2, 140148.

Almazán Rueda, P. (2004): Towards assessment of welfare in African catfish, Clarias gariepinus: the first step. PhD dissertation, Wageningen University, Wageningen, The Netherlands.

AOAC Association of Official Analytical Chemist (2000): Official methods of analysis $16^{\text {th }}$ edition. Arlington Virginia

Appelbaum, S., Kamler E. (2000): Survival, growth, metabolism and behaviour of Clarias gariepinus (Burchell, 1822) early stages under different light conditions. Aquaculture Engineering, 22, 269-287.

Appelbaum, S., McGeer, J. C. (1998): Effect of diet and light regime on growth and survival of African catish (Clarias gariepinus) larvae and early juveniles. Aquaculture Nutrition 4, 157- 164

Bardócz, T., Kovăcs, É., Radics, F. Săndor, Z. (1999): Experiments for the improved use of decapsulated Artemia cysts in intensive culture of African catfish larvae. Journal of Fish Biology 55 (Supplement A): 22 7-232.

Billard, R., Lecointre G. (2001): Biology and conservation of sturgeon and paddle fish. Reviews in Fish Biology and Fisheries, 10, 355-392.

Biswas, A. K., Seoka, M. T., Anaka, Y., Takii, K., Kumai, H. (2006): Effect of photoperiod manipulation on the growth performance and stress response of juvenile red sea bream (Pagrus major). Aquaculture, 258, 350-356.

Bransden, M.P., Butterfield, G.M., Walden, J., McEvoy, L.A., Bell, J.G. (2005): Tank colour and dietary arachidonic acid affects pigmentation, eicosanoid production and tissue fatty acid profile of larval Atlantic cod (Gadus morhua). Aquaculture, 250, 328-340.

Britz, P. J., Pienaar, A. G. (1992): Laboratory experiments on the effect of light and cover on the behaviour and growth of African catfish, Clarias gariepinus (Pisces: Clariidae). Journal of Zoology London, 227, 43-62.

Cox, E. S., Pankhurst, P. M. (2000): Feeding behaviour of green back founder larvae, Rhombos oleatapirina (Gunther) with differing exposure histories to live prey. Aquaculture, 183, 285-297.

De Silva, S. S. (2001): A global perspective of aquaculture in the new millennium. In R.P. Subasinghe, P. Bueno, M.J. Phillips, C. Hough, S.E. McGladdery and J.R. Arthur, eds. Aquaculture in the Third Millennium. Technical Proceedings of the Conference on Aquaculture in the Third Millennium, Bangkok, Thailand, 20-25 February 2000. pp. 431 - 459. NACA, Bangkok and FAO, Rome, Italy.

Ekokotu, O. A., Nwachi, O. F. (2014): The growth performance of Clarias gariepinus fries raised in varying co- loured receptacles. Journal of Research in Biology, 4, 1287-1292.

Eslamloo, K., Akhavan, S.R., Eslamifar, A., Henry, M.A. (2007): Effects of background colour on growth performance, skin pigmentation, physiological condition and innate immune responses of goldfish, Carassius auratus. Aquaculture Research, 46, 202-215.

Fafioye, O. O., Fagade, S.O., Adebisi, A.A., Jenyo, O., Omoyinmi, G.A.K. (2005). Effects of dietary soybeans (Glycine $\max ($ L.) Merr.) on growth and body composition of African catfish (Clarias gariepinus, Burchell) Fingerlings. Turkish Journal of Fisheries and Aquatic Sciences, 5, 11-15.

FAO (2007): Status of world fisheries and aquaculture (2014): FAO fisheries and aquaculture department. FAO, Rome, Italy. $243 \mathrm{pp}$

FAO (2014): Status of world fisheries and aquaculture: Opportunity and challenges. FAO, Rome, Italy. $243 p p$

Hecht, T., Appelbaum, S. (1987): Notes on the growth of Israeli sharptooth catfish (Clarias gariepinus) during the primary nursing phase. Aquaculture, 63, 195-204.

Henne, J. P., Watanabe, W. O. (2003): Effect of light intensity, salinity on growth, survival and whole body osmolarity of larval. Southern flounder Paralichtys letostigma. Journal world Aquaculture Sacrifice, 34: 450- 465.

Höglund, E., Balm, P. H. M. Winberg, S. (2002): Behavioural and neuroendocrine effects of environmental background colour and social interaction in Arctic charr (Salvelinus alpinus). The Journal of Experimental Biology, 205, $2535-2543$.

Jegede, T. (2011): Effects of colour on growth of Oreochromis niloticus (Linnaeus 1757) fingerlings. International Journal of Biochemistry Science, 5, 371-374.

Karakatsouli, N., Papoutsoglou, S.E., Manolessos, G. (2007): Combined effects of rearing density and tank colour on the growth and welfare of juvenile white sea bream ( $D i$ plodus sargus, L.) in a recirculating water system. Aquaculture Research, 38, 1152-1160.

Khan, J. R., Trembath, C., Pether, S., Bruce, M., Walker, S. P., Herbert, N. A. (2014): Accommodating the cost of growth and swimming in fish-the applicability of exercise-induced growth to juvenile hapuku (Polyprion oxygeneios). Frontiers in physiology, 5, 448. doi: 10.3389/ fphys.2014.00448.

Manjappa, K., Keshavanath, P., Gangadhara, B. (2011): Influence of Sardine oil supplemented fish meal free diets on common carp (Cyprinus carpio) Growth, carcass composition, and digestive enzyme activity. Journal of Fisheries and Aquaculture Sciences, 12, 1-10.

Martinez-Cardenas, L., Purser, G. J. (2007): Effect of tank colour on Artemia ingestion, growth and survival in cultured early juvenile pot-bellied seahorses (Hippocampus abdominalis) Aquaculture, 264, 92-100.

Martínez-Porchas, M., Martínez-Córdova, L. R., Ramos-En- 
riquez, R. (2009): Cortisol and glucose: reliable indicators of fish stress. Pan-American Journal of Aquatic Sciences, 4, 2, 158-178.

Martin-Robichaud, D. J., Peterson, R. H. (1998): Effects of light intensity, tank colour and photoperiod on swim bladder inflation success in larval striped bass (Morone saxatilis, Walbaum). Aquaculture Research 29, 539-547.

McLean, E., Cotter, P., Thain, C., King, N. (2008): Tank colour impact performance on culture fish. Croatian Journal of Fisheries, 66, 2, 43-54.

Merighe, G. K. F., Pereira-da-Silva, E. M., Negrão, J. A. Ribeiro, S., (2004): Effect of background colour on the social stress of Nile tilapia (Oreochromis niloticus). Revista Brasileira de Zootecnia, 33, 828-837.

Okomoda, V. T., Tiamiyu, L. O., Iortim, M. (2016): The effect of water renewal on growth of Clarias gariepinus fingerlings. Croatian Journal of Fisheries, 74, 25-29.

Opiyo, A.P. (2010): Influence of stocking density and background colour on the growth performance and survival of Nile tilapia fry (Oreochromis niloticus), Unpublished MSc thesis submitted to Department of Fisheries and Aquatic Sciences (Aquaculture), Moi University, Nigeria 67pp.

Ostrowski, A. C. (1989): Effect of rearing tank background colour on early survival of dolphin larvae, Coryphaena hippurus. The Progressive Fish Culturist 51, 161-163.

Ozorio, R.O.A. (2008): Swimming Activity and Non-Protein Energy (NPE) Metabolism in Fish. Current Nutrition and Food science, 4, 282-289.

Palstra, A. P., Planas, J. V. (Eds.). (2012): Swimming Physiology of Fish: Towards using exercise to farm a fit fish in sustainable aquaculture. Springer Science \& Business Media.

Papoutsoglou, S. E., Karakatsouli, N., Chiras, G. (2005): Dietary L-tryptophan and tank colour effects on growth performance of rainbow trout (Oncorhynchus mykiss) juveniles reared in a recirculating water system. Aquaculture Engineering 32, 277-284.

Papoutsoglou, S. E., Mylonakis, G., Miliou, H., Karakatsouli, N. P., Chadio, S. (2000): Effects of background colour on growth performances and physiological responses of scaled carp (Cyprinus carpio L.) reared in a closed circulated system. Aquaculture Engineering 22, 309-318.
Pottinger, T. G., Carrick, T. R., Yoemans, W. E. (2002): The three-spined stickleback as an environmental sentinel: effects of stressors on whole-body physiological indices; Journal of Fish Biology, 61, 207-229.

Rodriguez, H. (2013): IT8 colour target by EGM laboratories. jpg, https://commons.wikimedia.org/wiki/File:IT8_color_target_by_EGM_Laboratories.jpg

Rotllant, J., Tort L., Montero, D., Pavlidis M., Martinez, M., Wendelaar Bonga, S. E., Balm, P.H.M. (2003): Background colour influence on the stress response in cultured red porgy (Pagrus pagrus). Aquaculture 223, 129139.

Solomon, S. G., Okomoda, V. T. (2012b): Effects of photoperiod on some biological parameters of Clarias gariepinus juveniles. Journal of Stress Physiology and Biochemistry, 8, 47-54.

Solomon, S.G., Okomoda, V.T., (2012a): Growth response and aggressive behaviour of Clarias gariepinus fingerlings reared at different photoperiods in a water re-circulatory system. Livestock Research for Rural Development. 24 (11). available at: http://www.Irrd.org/Irrd24/11/ shol24191.htm

Srivastava, S., Choudhary, S.K. (2010): Effect of artificial photoperiod on the blood cell indices of the catfish, Clarias batrachus. Journal of Stress Physiology and Biochemistry, 6, 22-32.

Stefansson, S. O., Hansen, T., (1989): Effects of tank colour on growth and smoltification of Atlantic salmon (Salmo salar L.). Aquaculture, 81, 379-386.

Strand, A., Alanärä, A., Staffan, F., Magnhag, C. (2007): Effects of tank colour and light intensity on feed intake, growth rate and energy expenditure of juvenile Eurasian perch, (Perca fluviatilis, L.). Aquaculture, 272, 312-318.

Tacon, A.G.J., Forster, I. P. (2001): Global trends and challenges to aquaculture and aquafeeds development in the new millennium. International Aquafeeds-Directory and Buyers Guide: 4-25.

Yasharian, D., Coyle, S.D., Tidwell, J.H., Stilwell, W.E. (2005): The effect of tank colouration on survival, metamorphosis rate, growth and time to metamorphosis freshwater prawn (Macrobrachium rosenbergii) rearing. Aquaculture Research, 36, 278-283. 